60th passage. The cultured organisms retained their characteristic helical morphology and motility in $\mathrm{H}-1$ medium. Under the same growth conditions, SMCA reached titers of $6 \times 10^{8}$ organisms per milliliter in SP-4 medium, with an exponential doubling time of 6 hours. At $37^{\circ} \mathrm{C}$, strain SMCA achieved titers in complete $\mathrm{H}-\mathrm{l}$ medium that were comparable to those at $30^{\circ} \mathrm{C}$. Adaptation of strain SMCA to $\mathrm{H}-1$ medium without sphingomyelin was very slow. Even after 60 passages in this medium variation, the spiroplasma reached titers of no more than $5 \times 10^{6}$ organisms per milliliter in 5 days at $30^{\circ} \mathrm{C}$. At $37^{\circ} \mathrm{C}$, spiroplasmas in the absence of sphingomyelin became essentially spherical within 24 hours, showed no evidence of multiplication, and were not viable (that is, they did not multiply when transferred to SP-4 medium).

Growth rates of spiroplasmas in conventional media vary enormously. Although some of the fastest growing spiroplasmas have been cultivated in defined media, slowgrowing spiroplasmas had remained noncultivable in defined formulations (26). Prior to this study, $S$. mirum had been thought of as one of the slowest growing spiroplasmas, and it had been feared that its biochemical pathways and their pathogenic consequences could be studied only in undefined medium. Medium $\mathrm{H}-\mathrm{l}$ and the important growth factor sphingomyelin provide new opportunities for studying the metabolic basis for pathology induced by $S$. mirum in vertebrates. The critical importance of sphingomyelin for in vitro cultivation of strain SMCA at the mammalian body temperature of $37^{\circ} \mathrm{C}$, the association of sphingomyelin with plasma membranes, particularly of neural and hepatic tissues (27), and the multiplication and persistence of $S$. mirum in the brain, retina, and liver of inoculated mice $(1,7,8)$ suggest that sphingomyelin dependency should be investigated as a possible factor determining $S$. mirum tissue tropism and pathogenesis in mammals.

\section{REFERENCES AND NOTES}

1. H F. Clark, J. Infect. Dis. 114, 476 (1964); and L. B. Rorke, in The Mycoplasmas, R. F. Whit comb and J. G. Tully, Eds. (Academic Press, New York, 1979), vol. 3, pp. 155-174.

2. J. W. Bastardo, D. Ou, R. H. Bussell, Infect. Immun 9, 444 (1974).

3. R. F. Zeigel and H F. Clark, ibid., p. 430.

4. J. G. Tully, R. F. Whitcomb, D. L. Williamson, H F. Clark, Nature (London) 259, 117 (1976)

5. R. F. Whitcomb, Annu. Rev. Microbiol. 34, 677 (1980).

6. J. G. Tully, R. F. Whitcomb, D. L. Rose, J. M Bové, Int. J. Syst. Bacteriol. 32, 92 (1982).

7. H F. Clark, Progr. Med. Virol. 18, 307 (1974).

8. A. Fabivi, T. S. Elizan, J. E. Pounds, Proc. Soc. Exp. Biol. Med. 136, 88 (1971); F. O. Bastian, D. M Purnell, J. G. Tully, Am. J. Pathol. 114, 496 (1984) H F. Clark and D. T. Karzon, J. Immunol. 101, 776 (1968); T. S. Elizan, A. Fabivi, H F. Clark, Proc. Soc.
Exp. Biol. Med. 139, 51 (1972); J. Schwartz and T. Elizan, ibid. 141, 699 (1972)

9. G. J. McGarrity, F. Megraud, L. Gamon, Ann. Microbiol. (Inst. Pasteur) 135A, 249 (1984).

10. H. Kotani, D. Philips, G. J. McGarritv, In Vitro 22 , 756 (1986)

11. J. G. Tullv, R. F. Whitcomb, H F. Clark, D. L. Williamson, Science 195, 892 (1977).

12. R. C. Parker, L. N. Castor, E. A. McCulloch, Spec Publ. N.Y. Acad. Sci. 5, 303 (1957); G. M. Healy D. C. Fisher, R. C. Parker, Proc. Soc. Exp. Biol. Med. 89, 71 (1955)

13. J. G. Tully et al., Science 212, 1043 (1981).

14. J. G. Tully, D. L. Rose, R. F. Whitcomb, R. P Wenzel, J. Infect. Dis. 139, 478 (1979).

15. J. G. Tully, D. Tavlor-Robinson, D. L. Rose, R. M Cole, J. M. Bové, Int. J. Syst. Bacteriol. 33, 387 (1983).

16. C. J. Chang and T. A. Chen, Science 215, 1121 (1982); C. J. Chang and R. E. Wilkinson, in Structure, Function and Metabolism of Plant Lipids, P.-A. Siegenthaler and W. Eichenberger, Eds. (Elsevier, New York, 1984), pp. 357-364; I.-M. Lee and R. E. Davis, Appl. Environ. Microbiol. 46, 1247 (1983).

17. The basal fraction of the medium was prepared as follows. To $70 \mathrm{ml}$ of warm $\left(30^{\circ} \mathrm{C}\right)$ sterile distilled water, add in sequence (while stirring): Hepes buffer, amino acids, organic acids, inorganic salts, nucleic acid precursors, cofactors, carbohydrates, vitamins and reducing agents, phenol red, and penicillin. (Constituents, particularly vitamins, were sometimes added as stock solutions.) Titrate to $\mathrm{pH} 7.4$ with $\mathrm{lN} \mathrm{NaOH}$. Make up to $80 \mathrm{ml}$, then add $20 \mathrm{~m}$ of the lipid-bovine serum albumin (BSA) fraction [serum substitute (18)] dropwise to $80 \mathrm{ml}$ of the basal fraction. Sterilize by filtration $(0.22-\mu \mathrm{m}$ pore

diameter), store at $4^{\circ} \mathrm{C}$, and dispense in aliquots of $0.9 \mathrm{ml}$ to test tubes, as needed.

18. Preparation of serum substitute. To $2.0 \mathrm{ml}$ of warm $\left(30^{\circ} \mathrm{C}\right.$ ) $100 \%$ ethanol, add (while stirring): $5 \mathrm{mg}$ of palmitic acid, $5 \mathrm{mg}$ of oleic acid, $10 \mathrm{mg}$ of cholesterol, $10 \mathrm{mg}$ of sphingonvelin, $0.05 \mathrm{ml}$ of Tween 40 and $0.05 \mathrm{ml}$ of Tween 80 . While stirring, add $0.4 \mathrm{~m}$ of this preparation dropwise to $19.6 \mathrm{ml}$ of $6 \% \mathrm{BSA}$ (essentially fatty acid-free, No. A-7511, Sigma) and adjust to $p \mathrm{H} 7.4$ with $\mathrm{iN} \mathrm{NaOH}$. Sterilize by filtration $(0.22-\mu \mathrm{m}$ pore diameter) and store at $26^{\circ} \mathrm{C}$.

19. B. A. Freeman et al., J. Bacteriol. 125, 946 (1976).

20. J. B. Mudd, M. Ittig, B. Roy, J. Latrille, J. M. Bové ibid. 129, 1250 (1977).

21. Z. Gross and S. Rottem, Biochim. Biophys. Acta 778 , 372 (1984)

22. P. J. Davis et al., J. Bacteriol. 161, 118 (1984)

23. R. G. Cluss and N. L. Somerson, Appl. Environ. Microbiol. 43, 412 (1982)

24. D. L. Williamson, R. F. Whitcomb, J. G. Tully, Curr. Microbiol. 1, 203 (1978)

25. Titers were determined by making serial dilutions in SP-4 medium, $0.2 \mathrm{ml}$ of medium per $0.4-\mathrm{ml}$ microtiter plate well. Assavs were done daily, with three series of dilutions per assav.

26. C. J. Chang in The Mycoplasmas, R. F. Whitcomb and J. G. Tully, Eds. (Academic Press, New York, in press), vol. 5

27. L. Strver, Biochemistry (Freeman, San Francisco, ed. 2, 1981), p. 206.

28. Supported by Binational Agricultural Research and Development agreements 58-32R6-3-157 and 58 32U4-6-165. We thank G. J. McGarrity for helpfu suggestions in preparation of the manuscript.

9 February 1987; accepted 12 May 1987

\title{
Identification of a Family of Muscarinic Acetylcholine Receptor Genes
}

\author{
T. I. Bonner, N. J. Buckley, A. C. Young, M. R. Brann
}

Complementary DNAs for three different muscarinic acetylcholine receptors were isolated from a rat cerebral cortex library, and the cloned receptors were expressed in mammalian cells. Analysis of human and rat genomic clones indicates that there are at least four functional muscarinic receptor genes and that these genes lack introns in the coding sequence. This gene family provides a new basis for evaluating the diversity of muscarinic mechanisms in the nervous system.

$\mathrm{M}$

USCARINIC RECEPTORS MEDIATE many of the actions of acetylcholine in the central and peripheral nervous systems (1). Two pharmacologically distinct classes of such receptors, $\mathrm{Ml}$ and M2, have been defined on the basis of their affinities, high and low, respectively, for the antagonist pirenzepine (2). However, a variety of heterogeneous properties of muscarinic receptors have not always correlated well with this classification, which suggests that there may be other classes. It has been unclear whether the apparently different receptors represent modifications of a single receptor or whether they are different proteins. Recently a porcine brain muscarinic receptor complementary DNA (cDNA) was cloned and expressed in Xenopus oocytes to produce functional receptors (3). The presence of related messenger RNA (mRNA) in tissues rich in $\mathrm{Ml}$ receptors and its absence in tissues rich in $\mathrm{M} 2$ receptors suggested that there is more than one muscarinic acetylcholine receptor gene. More recently a related porcine cardiac $\mathrm{CDNA}$ sequence with the tissue distribution expected of $\mathrm{M} 2$ receptors was reported (4). Although no expression data were presented to verify that it is a muscarinic receptor, its identity has since been confirmed by expression of the porcine gene (5) and the corresponding human gene in mammalian cells.

Muscarinic receptors are members of a large class of neurotransmitter, hormone, and light receptors which act through binding to and activation of guanosine $5^{\prime}$-tri-

T. I. Bonner, N. J. Buckley, A. C. Young, Laboratory of Cell Biology, National Institute of Mental Health, Bethesda, MD 20892.

M. R. Brann, Metabolic Diseases Branch, National Insti tute of Diabetes, Digestive and Kidney Diseases, Bethesda, MD 20892. 
phosphate $(\mathrm{G})$ binding proteins. The activated $G$ proteins can stimulate or inhibit adenylate cyclase, stimulate phosphatidylinositol turnover, and directly regulate ion channels, thereby effecting a variety of cellular responses (6). Other members of this class that have recently been cloned are the visual pigment proteins or opsins $(7)$ and $\beta$ adrenergic receptors $(8,9)$. Hydrophobicity analysis of each of these receptor sequences suggests the presence of seven transmembrane domains. In fact, they all have sub- stantial amino acid sequence conservation, especially in regions proposed to be transmembrane domains $(3,8)$. The sequence conservation among these receptors suggested that cDNAs of other receptors coupled to $G$ proteins might be isolated by hybridization to probes derived from the highly conserved regions. Using such a probe to screen a rat cerebral cortex cDNA library, we isolated three different clones. One of these clones is the rat homolog of the porcine brain muscarinic receptor. The oth- er two clones are closely related to, but distinct from, the brain and cardiac muscarinic receptors; expression of these clones in mammalian cells establishes that they are also muscarinic receptors.

Our cloning strategy for the most effective identification of a variety of $G$ proteincoupled receptors had three major components. (i) We used a rat cerebral cortex cDNA library of $7 \times 10^{6}$ clones in the $\mathrm{pcD}$ mammalian expression vector $(10)$, which favors production of relatively complete

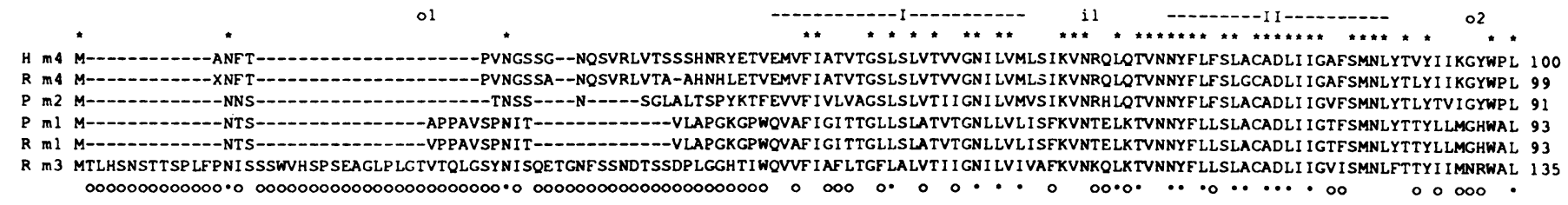

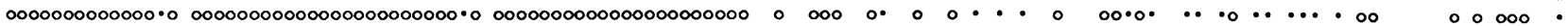

H 44 GAVVCDLWLALDYVVSNASVMNLLI ISFDRYFCVTKPLTYPARRTTKMAGLMIAAAWVLSFVLWAPAILFWRFVGKRTVPDNHCFIQFLSNPAVTFGTAIAAFYLPVIIMTVLYIHISLASRSRVHKHRPEGP 234 $R$ m 4 GAVVCDLWLALDYVVSNASVMNLLI I SFDRYFCVTKP LTYPARRTTKMAGLMI AAAWVLSFVLWAPAI LFWOFVVGKRTVPDNOCF IQFLSNPAVTFGTAIAAFY LPVVIMTVLY IH I SLASRSRVHKHRPEGP 233 $P$ m2 GPVVCDLWLALDYVVSNASVMNLLI I FFDYFCVTKP LTYPVKRTTKMAGMMI AAAWVLSF I LWAPA I LFWOF IVGVRTVEDGECY IQFFSNAAVTFGTAI AAFY LPVI IMTVLYWH I SRASKSR I KKDKKEPV 225 $P$ ml GTLACDLWLALDYVASNASVMNLLL I SFDRYFSVTRP LSYRAKRTPRRAALMI GLAWLVSFV LWAPA I LFWQY LVGERTVLAGQCY IQFLSOP I ITFGTAMAAFY LPVTVMCTLYWR I YRE TENRARELAALOG 227 $R \mathrm{~m} 1$ GTLACDLWLALDYVASNASVMNLLLI SFDRYFSVTRP LSYRAKRTPRRAALMI GLAWLVSFVLWAPA I LFWOY LVGERTVLAGQCY IQF LSOP I ITFGTAMAAFY LPVTVMCTLYWR I YRETENRARELAALOG 227 $R \mathrm{~m} 3$ GNLACDLWLSI DYVASNASVMNLLVI SFDRYF S ITRP LTYRAKRTTKRRGVMI GLAWVI SFVLWAPA I LFWOYFVGKRTVPPGECF IQFLSEPT ITFGTAI AAFYMPVT IMT I LYWR I YKETEKRTKELAGLOA 269

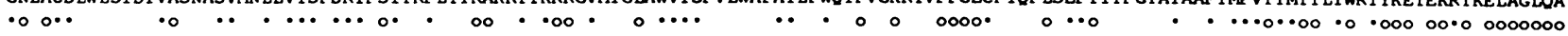

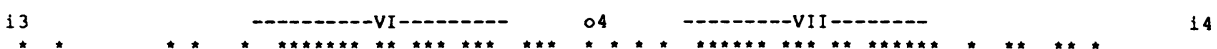

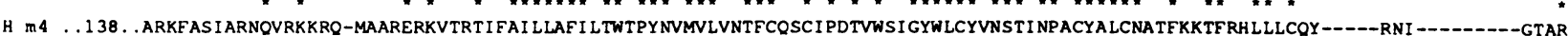
R m 4 .. 139. . ARKFAS I ARNQVRKKRQ-MAARERKVTRT I FAI LLAFI LTWTPYNVMVLVNTFCQSCI PETVWSI GYWLCYVNSTI NPACYALCNATFKKTFRHLLLCQY-----RNI ----------GTAR

P m2 .136. .VARK IVKMTKOPAKKKP-PP SREKKVTRTIFAI LLAFI I TWAPYNVMVLI INTFCAPCI PNTVWTI GYWLCY INSTI NPACYALCNATFKKTFKH LIMCHY-----KNI ------_---GATR

P $\mathrm{m} 1 \ldots 121 \ldots$. GKGQKPRGKEOLAKRKTF SLVKEKKAARTLSA I LLAF I VTWTPYNIMVLVSTFCKDCVPE TLWELGYWLCYVNSTI NPMCYALCNKAFRDTFRLLLLCRWDKRRWRKI PKRPGSVARTP SROC

$R \mathrm{~m} 1 \ldots 121$. GKGQKPRGKEQLAKRKTF SLVKEKKAARTLSAI LLAFI LTWTPYNI MVLVSTFCKDCVRETLWELGYWLCYVNSTVNPMCYALCNKAFRDTFRLLLLCRWDKRRWRK I PKRPGSVHRTP SROC

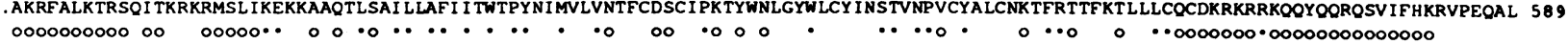

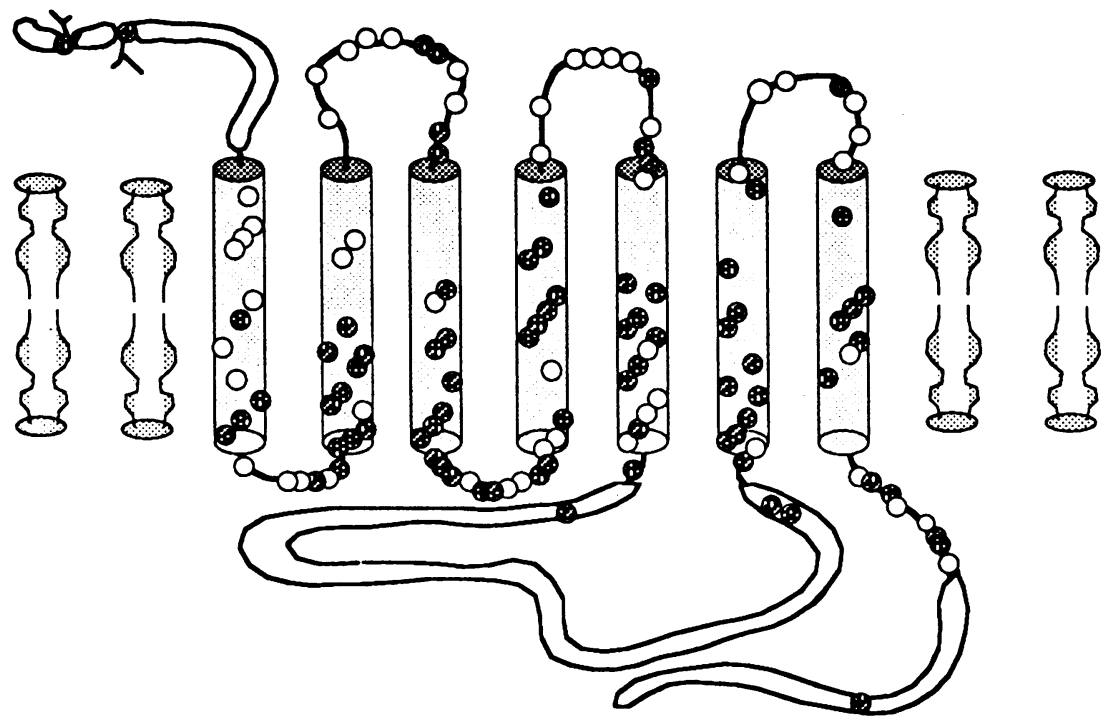

Fig. 1. Comparison of the deduced amino acid sequences of receptors $\mathrm{ml}$ through $\mathrm{m} 4$. The names of the sequences are prefixed with $\mathrm{P}$ (pig), $\mathrm{R}$ (rat), or $\mathrm{H}$ (human) to identify the species. Dashes signify gaps introduced to align the sequences. The transmembrane domains of the proteins are delineated by dashes above the sequence and are numbered I through VII. The proposed outer and inner domains are labeled, respectively, ol through o4 and il through i4. Asterisks immediately above the aligned sequences indicate positions at which all the muscarinic sequences are identical. Open circles below the sequences indicate positions at which there are nonconservative substitutions in at least one muscarinic sequence where conservative substitutions are defined as changes between members of one of the following groups: S (Ser), T (Thr), P (Pro), A (Ala), and G (Gly); N (Asn), D (Asp), E (Glu), and Q (Gln); H (His), K (Lys), and R (Arg); M (Met), I (Ile), L (Leu), and V (Val); F (Phe), Y (Tyr), and W (Trp); or C (Cys) (26). Dark dots below the sequence identify positions at which there are only conservative changes when this group is compared to the rhodopsin and $\beta$-adrenergic receptor sequences. Most of the amino acids in i3 have not been aligned since they show almost no sequence identity between different receptors. A schematic diagram of the receptors is shown at the bottom with dark circles representing the residues conserved in thodopsin and $\beta$-adrenergic receptor and open circles or boxes representing positions at which there are nonconservative changes within the muscarinic sequences. 
cDNAs and which facilitates the expression of clones in mammalian cells. (ii) We used as probe a sequence that not only was highly conserved among the known receptor sequences but also was located near the $5^{\prime}$ end of the coding sequence so that cDNAs that hybridized were likely to contain the complete coding sequence. The sequence chosen (3'-TC TGT CAG TTG TTG ATG AAG GAC GAC TCG GAC CGG ACA CGA CTG GAG TAG TAC CCG-5') was taken from the beginning of the second transmembrane region of the porcine brain CDNA (nucleotides 170 to 225 of the noncoding strand) but modified at positions 5,38 , and 53 to more accurately reflect mammalian codon usage and to better approximate the hamster $\beta$-adrenergic receptor sequence from which it differs by 14 bases. (iii) We characterized the clones before isolation by using Southern blots of portions of the library containing as many as $5 \times 10^{5}$ clones, a procedure that was facilitated by having a plasmid rather than a phage vector (11). Assuming that the first two components have assured that all the detectable clones corresponding to a particular message are nearly the same size, the blots allowed us to focus on representatives of the major size classes revealed with a given restriction enzyme (Xho I or Bam HI) and within the size classes to focus on the largest cDNA. Once a band of interest was identified, the pool containing the band was used to start new cultures containing tenfold fewer clones per pool and the blot analysis was repeated. Two to three cycles of subdivision allowed a pool to be produced in which the band of interest was the only hybridizing band and from which the corresponding clone was easily isolated by colony hybridization. The validity of the strategy is established by the fact that the first four clones (12) represented three different gene products and contained the complete coding sequence of two of them. The use of these clones as probes to reexamine the whole library at high stringency indicated that there were no copies of these cDNAs in the library that were substantially longer than the ones we had isolated.

The amino acid sequences derived from the three cDNA sequences (13) are compared to each other and the porcine receptors in Fig. 1. The second clone isolated encodes a 458-amino acid protein with potential glycosylation sites at residues 2 and 12 . The $98 \%$ identity of this clone to the porcine $\mathrm{ml}$ clone establishes that it is the rat homolog and it will accordingly be called the $\mathrm{ml}$ clone (14). Of the ten amino acid substitutions, three are located near the amino terminus ( $\mathrm{Val} \rightarrow \mathrm{Ala}_{5}$ ), in transmembrane region VI ( $\left.\mathrm{Leu} \rightarrow \mathrm{Val}_{374}\right)$, and in transmembrane region VII (Val $\rightarrow \mathrm{II}_{411}$ ) whereas the remainder are in the large loop between regions VI and VII. By analogy with the structure of rhodopsin where the extracytoplasmic and cytoplasmic loops are identified (15), this loop is presumably cytoplasmic. The fourth clone isolated encodes a 589-amino acid protein with potential glycosylation sites at amino acids $6,15,41,48$, and 52 whereas the third clone isolated represents an incomplete version of this clone. Since it differs from both the $\mathrm{ml}$ clones and the porcine $\mathrm{m} 2$ clone but will be shown below to be a muscarinic receptor, it will be referred to as the $\mathrm{m} 3$ receptor. The first clone isolated does not contain the complete coding sequence, but comparison with the corresponding human gene suggests that it lacked only the first five nucleotides of the coding sequence. Two additional cDNAs of approximately the same size were isolated and proved to begin at exactly the same position even though differing lengths of the G tails, which were used to prime the synthesis of the second strand of cDNA, suggested that they were independent clones. Assuming the first five nucleotides are the same as those in the human gene, this cDNA would encode a protein of 478 amino acids with potential glycosylation at residues 3,8 , and 13 . This clone is called the $\mathrm{m} 4$ receptor.

Comparison of these sequences with those of the porcine receptors shows a high degree of conservation in the regions corresponding to postulated transmembrane regions I through V and VI through VII with much less homology in the amino and carboxyl terminal regions (preceding region I or following region VII). In addition, the large cytoplasmic loop between transmembrane regions $\mathrm{V}$ and VI is variable in size (157 to 203 amino acids) and shows little similarity among $\mathrm{ml}$ through $\mathrm{m} 4$ except for a large fraction (17 to $20 \%$ ) of basic residues. This loop is much smaller (approximately 30 to 50 residues) in the $\beta$-adrenergic receptor and rhodopsin. With this loop and the amino and carboxyl terminals excluded from the comparison, the $\mathrm{m} 3$ sequence has $79 \%$ identity to the $\mathrm{ml}$ sequence and the $\mathrm{m} 4$ sequence has $65 \%$ identity to $\mathrm{ml}$. However, $\mathrm{m} 4$ is more closely related to the porcine $\mathrm{m} 2$ sequence with $85 \%$ identity. The much poorer homology in the amino terminal and large cytoplasmic loop indicates that $\mathrm{m} 4$ is not the rat homolog of the porcine $\mathrm{m} 2$. Cloning of two different human genes closely related (97 and $95 \%$ overall) to $\mathrm{m} 2$ and $\mathrm{m} 4$, respectively, confirms that they are distinct genes. The nonconservative substitutions in the muscarinic receptor sequences are located primarily in the $\mathrm{i} 3$ and $\mathrm{i} 4$ cytoplasmic domains and in the ol through o4 external domains. The positions at which only conservative changes occur in the muscarinic, adrenergic, and opsin sequences are clustered in the inner half of the transmembrane domains and near the inner face of the membrane.

The $\mathrm{ml}$ and $\mathrm{m} 3$ rat genes were isolated from a partial Eco RI rat genomic library (16) and sequenced. All but 20 nucleotides of the $\mathrm{m} 3 \mathrm{cDNA}$ sequence are found in a single continuous stretch of 3507 bases; this result demonstrates that there are no introns in the coding or $3^{\prime}$ untranslated sequence. However, since the cDNA and gene sequences diverge prior to base -19 (numbering from the first base of coding sequence) and since the gene sequence at this point $(-40$ to -20$)$ matches the consensus splice acceptor sequence (17), there must be an intron in the $5^{\prime}$ untranslated sequence. Similarly the entire 2528 bases of the mil cDNA is found in a continuous stretch in the $\mathrm{ml}$ gene. There is a potential splice site at -83 to -70 of the gene sequence, which has been verified by ribonuclease mapping of the cerebral cortex message (18). We also screened a partial Hae III-Alu I human genomic library (19) and obtained the human $\mathrm{m} 2$ and $\mathrm{m} 4$ genes. The human $\mathrm{m} 4$ sequence encodes a 478-amino acid protein that differs from the rat protein by 24 amino acid substitutions, 1 amino acid deletion, and 1 amino acid insertion. Of the 25 amino acid changes, 15 occur in the large cytoplasmic loop and 6 occur in the amino terminal extracytoplasmic tail. This gene has no introns in the coding sequence but has a potential splice acceptor site 30 to 53 bases upstream of the initiation codon. The human $\mathrm{m} 2$ gene encodes a 466-amino acid protein which differs from the porcine $\mathrm{m} 2$ receptor by 13 amino acid substitutions, 11 of which occur in the large cytoplasmic loop. It also has no introns in the coding sequence but the 5 ' untranslated sequence is sufficiently well conserved relative to the pig m2 cDNA sequence to allow the identification of a splice acceptor site at bases -67 to -47 . Thus all four genes lack introns in the coding sequence and, as far as has been ascertained, in the $3^{\prime}$ untranslated sequence as well. In this regard they are similar to $\beta$ adrenergic receptor gene but differ from the mammalian opsins which have four introns interrupting the coding sequence. In contrast to the adrenergic receptor where no intron has as yet been identified in the 5' untranslated sequence, the muscarinic receptor genes contain either a splice site or a potential splice site less than 100 bases upstream of the initiation codon. The lack of introns in such a large coding sequence is unexpected for a multiple domain receptor in light of arguments that suggest that in- 
trons facilitate evolution of new functions by allowing reassortment of functional domains of proteins $(20)$.

To establish that the clones are actually muscarinic receptors we have expressed them in mammalian cells by making use of the SV40 promoter incorporated into the $\mathrm{pcD}$ vector. Because the $\mathrm{ml}$ and $\mathrm{m} 3$ rat cDNAs contained complete coding sequences, these clones could be used directly for transfection. However, because the $\mathrm{m} 4$ cDNA lacked an initiation codon, we have substituted human $\mathrm{m} 45^{\prime}$ untranslated and coding sequence for the rat coding sequence of the $\mathrm{m} 4 \mathrm{cDNA}$ clone, thereby making a hybrid DNA containing human coding and rat $3^{\prime}$ untranslated sequences. The two sequences were joined at an Avr II restriction site that occurs at the beginning of the $3^{\prime}$ untranslated sequence of both clones. Because there was no convenient restriction site in the 30 bases between the initiation codon and the possible splice acceptor site with which to join the coding sequence to the SV40 promoter, we used a Sac I site located 506 to 511 bases upstream and ligated it to the Bam HI site in the SV40 intron of the $\mathrm{pcD}$ vector, using the Bam

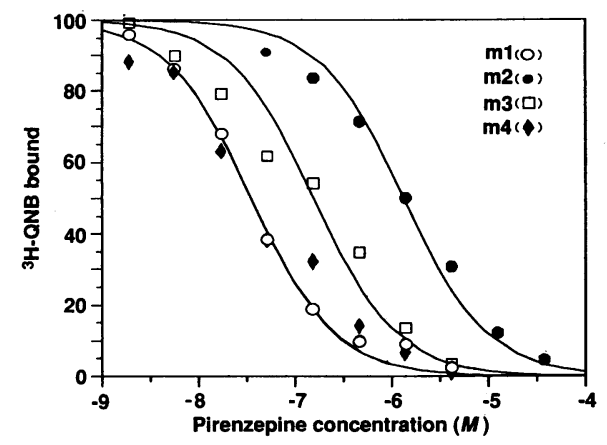

Fig. 2. Pharmacological characterization of muscarinic receptor clones. COS-7 cells $\left(2 \times 10^{6}\right.$ per $10-\mathrm{cm}$ plate) were cultured overnight and transfected with $20 \mu \mathrm{g}$ of plasmid DNA by calcium phosphate precipitation (27). Fresh medium was applied after 24 hours and cultures were incubated for an additional 24 hours, at which point cells were scraped from the dish, homogenized, and pelleted. The membranes were suspended in binding buffer $\left(10 \mathrm{~m} M\right.$ Hepes, $\left.p \mathrm{H} 7.4,5 \mathrm{~m} M \mathrm{MgCl}_{2}\right)$ at a protein concentration of $50 \mu \mathrm{g} / \mathrm{ml}$. Aliquots $(25 \mu \mathrm{g})$ were incubated for 2 hours at room temperature in a total volume of $1 \mathrm{ml}$ containing $100 \mathrm{p} M{ }^{3} \mathrm{H}-\mathrm{QNB}$ [adapted from (28)]. Nonspecific binding was defined with $1 \mu M$ atropine. Data were analyzed by nonlinear regression with the following function

$\%$ bound $=100-100\left(X / \mathrm{IC}_{50}\right) /\left(1+X / \mathrm{IC}_{50}\right)$

where $\mathrm{IC}_{50}$ is the inhibition constant, and $X$ is the ligand concentration. Lines are computer-generated fits to the data: $\mathrm{ml}, \mathrm{IC}_{50}=35 \pm 3 \mathrm{nM} ; \mathrm{m} 2$, $1340 \pm 190 \mathrm{n} M ; \mathrm{m} 3,156 \pm 38 \mathrm{n} M ;$ and $\mathrm{m} 4,36$ $\pm 8 \mathrm{n} M$. The affinity constants $\left(K_{\mathrm{D}}\right)$ for ${ }^{3} \mathrm{H}-\mathrm{QNB}$ for the $\mathrm{ml}(32 \mathrm{p} M), \mathrm{m} 2(59 \mathrm{p} M), \mathrm{m} 3(14 \mathrm{p} M)$, and $\mathrm{m} 4(81 \mathrm{p} M)$ transfectants were similarly determined with 2 to $200 \mathrm{p} M{ }^{3} \mathrm{H}-\mathrm{QNB}$.
HI-Sac I portion of the pUC18 multiple cloning site as a linker. This construct removes the $19 S$ splice acceptor as well as the SV40 $19 S$ initiation codon, forcing the use of an initiation codon in the human sequence and potentially using the putative human splice acceptor site. A similar construct was created with the human $\mathrm{m} 2$ gene and the rat $\mathrm{m} 4 \mathrm{cDNA}$ for expression of the human $\mathrm{m} 2$ receptor in which the $5^{\prime}$ end of the human sequence is defined by a Dra I site (-43) and the $3^{\prime}$ end by an Avr II site (1556 to 1561 ) in the $3^{\prime}$ untranslated region. The $5^{\prime}$ end was ligated to the $\mathrm{pcD}$ vector at the Pst I site which normally defines the 5' end of a cDNA using a Pst IHinc II linker from pUC18. The Avr II site was ligated to the Avr II site of the rat $\mathrm{m} 4$ cDNA so that most of the $3^{\prime}$ untranslated sequence and the polyadenylated tail are derived from the $\mathrm{m} 4 \mathrm{cDNA}$. The $\mathrm{ml}, \mathrm{m} 3$, and hybrid $\mathrm{m} 2$ and $\mathrm{m} 4$ DNAs were transfected into mouse fibroblast (A9) or COS-7 cells. To assay the transfectants for the presence of muscarinic receptor, membranes were prepared from the transfectants 48 hours after transfection and assayed for their ability to bind specifically the muscarinic antagonist $\left[{ }^{3} \mathrm{H}\right]$ quinuclidinyl benzilate $\left({ }^{3} \mathrm{H}\right.$ QNB). Transfected COS-7 cells expressed $2 \times 10^{4}$ to $2 \times 10^{5}$ receptors per cell in different experiments while transfected A9 cells expressed $1 \times 10^{4}$ to $2 \times 10^{4}$ receptors per cell. Neither host cell expressed any muscarinic receptors before transfection. Displacement of ${ }^{3} \mathrm{H}$-QNB binding with the selective antagonist pirenzepine (Fig. 2) demonstrated that $\mathrm{ml}, \mathrm{m} 3$, and $\mathrm{m} 4$ transfectants had a high affinity for pirenzepine. Thus the $\mathrm{ml}, \mathrm{m} 3$, and $\mathrm{m} 4$ receptors would probably have been previously classified as M1 receptors. Human $\mathrm{m} 2$ transfectants had a low affinity for pirenzepine, consistent with its M2 classification and the results with the porcine $\mathrm{m} 2$ clone (5). Displacement of ${ }^{3} \mathrm{H}-\mathrm{QNB}$ binding by the muscarinic agonist carbachol also displayed inhibition constant $\left(\mathrm{IC}_{50}\right)$ values in the micromolar range.

To determine how many muscarinic genes are in the genome, we have examined a genomic blot of rat and human DNA with a 516-base probe corresponding to transmembrane regions II to $\mathrm{V}$ of the rat $\mathrm{ml}$ gene (Fig. 3). Hybridization at moderate stringency reveals nine to ten bands in each rat digest and five or six bands in each human digest. Comparison of the restriction map of the rat $\mathrm{ml}$ and $\mathrm{m} 3$ genes and the human $\mathrm{m} 2$ and $\mathrm{m} 4$ genes as well as highstringency hybridization of the four genes allowed the identification of one and only one band in each digest as corresponding to each of the four known genes. Thus there are one or two additional members of the muscarinic gene family in the human genome and potentially as many as five additional members in the rat genome. The difference between the number of bands detected in rat and human suggests that some of these genes may be pseudogenes, but determination of their functionality will require their cloning and sequencing and, possibly, their expression.

As a first step in a detailed mapping of the distribution of the muscarinic receptors in the rat, we have performed in situ hybridization to mRNA with oligonucleotides (21)

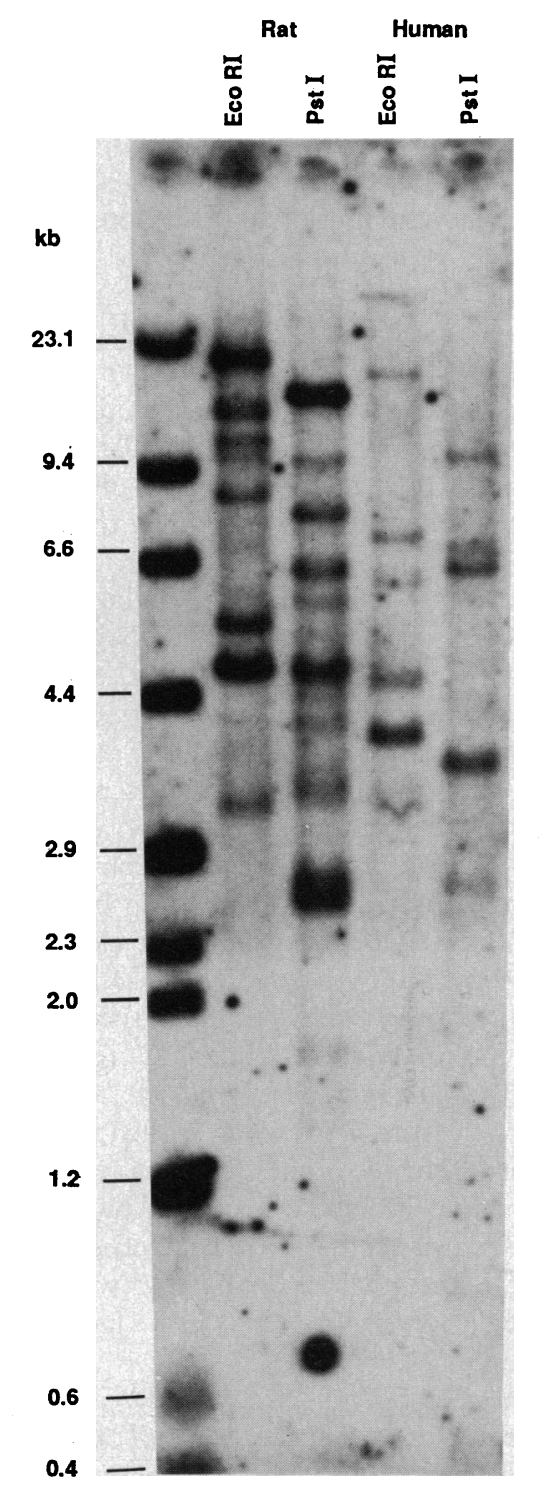

Flg. 3. Genomic blot of rat and human DNA. About $2 \mu \mathrm{g}$ of rat or human DNA was digested with Eco RI or Pst I, electrophoresed in a $0.7 \%$ agarose gel, and blotted onto nitrocellulose. The blot was hybridized to $\mathrm{CRmlp} 5$ probe in $3 \times$ SSC at $60^{\circ} \mathrm{C}$ and washed under the same conditions. The bands (rat Eco RI, rat Pst I, füman Eco RI, human Pst I; in kilobases) corresponding to individual receptor genes as identified by high-stringency hybridizations are: $\mathrm{ml}(4.8,2.7,3.8,3.5)$, $\mathrm{m} 2(8.5,2.8,6.2,11), \mathrm{m} 3(14,6.4,7.5,2.7)$, and $\mathrm{m} 4(20,1.7,18,0.8)$. 
derived from the amino terminal coding sequence of the rat $\mathrm{ml}, \mathrm{m} 3$, and $\mathrm{m} 4$ sequences. These probes are highly specific for the individual receptors since they have essentially no sequence homology to each other. On RNA blots they detected mRNA species of approximately 3000,5200 , and 3100 nucleotides for $\mathrm{ml}, \mathrm{m} 3$, and $\mathrm{m} 4$, respectively. All of these mRNA species were more abundant in brain than in heart. In situ hybridization (Fig. 4) indicates that $\mathrm{ml}, \mathrm{m} 3$, and $\mathrm{m} 4 \mathrm{mRNAs}$ are abundant in cerebral cortex, with $\mathrm{ml}$ and $\mathrm{m} 4$ uniformly distributed but $\mathrm{m} 3$ localized primarily in the inner and outer layers. The $\mathrm{ml}$ and $\mathrm{m} 3$ mRNAs are highly abundant in hippocampus but $\mathrm{ml}$ is much more abundant than $\mathrm{m} 3$ in the dentate gyrus; m4 mRNA is only moderately abundant in hippocampus and of low abundance in dentate gyrus. Thus Ml receptors previously characterized in brain are a mixture of $\mathrm{ml}, \mathrm{m} 3$, and $\mathrm{m} 4$ receptors.

Although there have been only two pharmacologically well-defined classes of muscarinic receptors, we have established that there are four distinct muscarinic receptor genes. Why are there so many if only a single subunit is required to make a functional receptor? A formal possibility is that the receptors are composed of heterogeneous subunits but that receptors formed from a single subunit will function in vitro. There is a precedent for such a proposal in the ability

Fig. 4. Localization of muscarinic receptor mRNA in a coronal section of rat brain: 48- or 45-base oligonucleotides complementary to sequence encoding amino acids 2 to 17 (m3: GCT GAT GTT GGG AAA CAA AGG CGA GGT TGT ACT GTT ACT GTG CAA GGT), 3 to 18 (ml: TGG TGC CAA GAC AGT GAT GTT GGG ACT GAC AGC AGG GGG CAC TGA GGT), or 3 to 17 (m4: GCG CAC AGA CTG ATT GGC TGA GCT GCC ATT GAC AGG CGT GAA GTT) of the rat receptors were ${ }^{35} \mathrm{~S}$-labeled and hybridized as described (21). The hybridized probe was visualized by exposure to $x$-ray film for 35 days. Regions rich in mRNA appear light, and nonspecific hybridization, as defined with similar probes to mRNAs not expressed in brain (transducin, rhodopsin), was homogeneous and equivalent to the darkest areas. Heavily labeled structures include the hippocampus $(\mathrm{H} ; \mathrm{ml}$ and $\mathrm{m} 3)$, and dentate gyrus (DG; $\mathrm{ml})$. Cortex $(\mathrm{CX})$ is moderately labeled with all three probes.

of the nicotinic acetylcholine receptor lacking either the $\gamma$ or $\delta$ subunits to function, albeit poorly (22). However, the available data on mRNA distribution indicate that there are large variations in the stoichiometry of the receptors, making this possibility seem less probable. The possibility of differential regulation of the mRNAs as indicated by their tissue specificity provides a partial justification for the number of different receptors. However, we suspect that the tissue specificity may in turn reflect an underlying functional variation. Cultured $1321 \mathrm{NI}$ astrocytoma cells have a muscarinic response characterized by a stimulation of phosphatidylinositol turnover but an absence of any adenylate cyclase inhibition whereas NG108-15 neuroblastoma-glioma hybrid cells show a muscarinic inhibition of adenylate cyclase but no stimulation of phosphatidylinositol turnover. These differences reflect a difference in the receptors rather than in the competence of the cells for the particular response when stimulated with other ligands (23). Thus the variety of receptor genes may well reflect specialization of different forms of the receptor for different coupling mechanisms. Since different types of muscarinic receptor are often mixed in a given tissue, cell lines stably expressing a single receptor will be essential in characterizing the different receptors (24).

A detailed study of the relation between the structure and function of the receptors
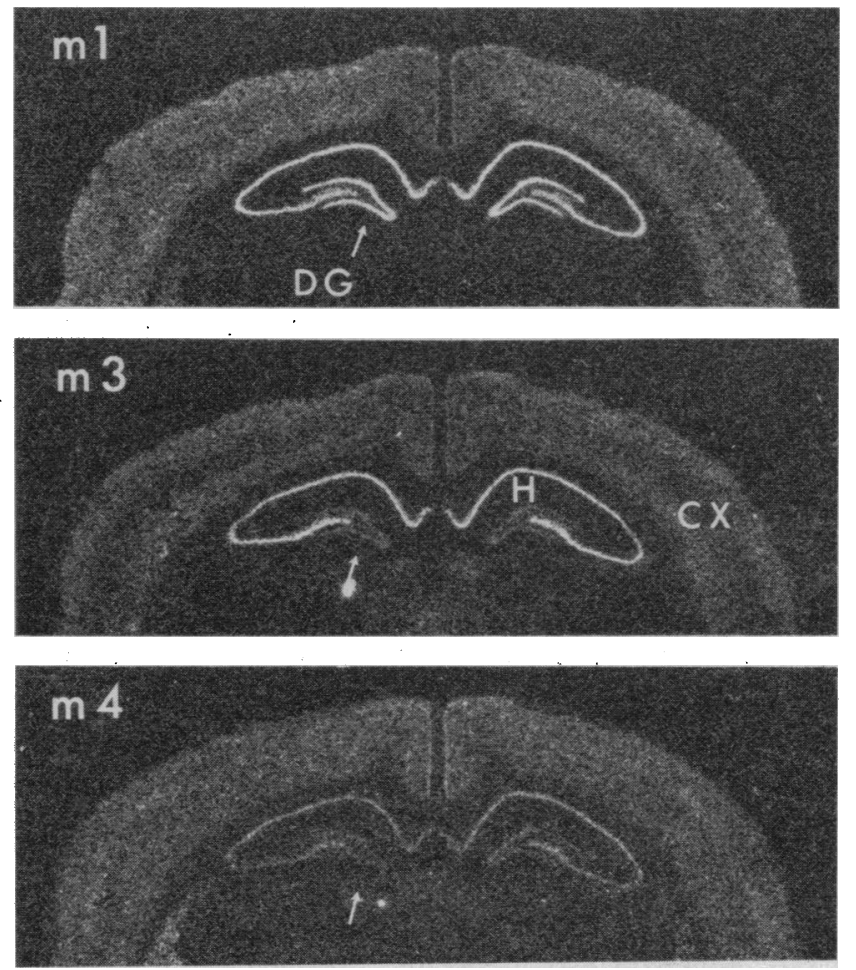

3I JULY 1987 should also be possible, with the similarities and dissimilarities in amino acid sequence of the four receptors providing valuable clues to structurally important features. Studies involving deletions of the extracytoplasmic loops of the $\beta$-adrenergic receptor (25) have already indicated that binding of ligand is not determined primarily by the extracytoplasmic domains, thereby implying that binding occurs to the transmembrane regions. The high degree of conservation of the i2 cytoplasmic loop suggests that it might be involved in the more general ability to bind $\mathrm{G}$ proteins. Because deletion from the carboxyl terminal of the i3 cytoplasmic loop eliminates adenylate cyclase stimulation in the $\beta$ receptor, this region may provide the specificity in cellular effector systems. Although this loop is highly variable among the muscarinic receptor types, it is nevertheless well conserved between species.

\section{REFERENCES AND NOTES}

1. N. M. Nathanson, Annu. Rev. Neurosci. 10, 195 (1987).

2. R. Hammer et al., Nature (London) 283,90 (1980)

3. T. Kubo et al., ibid. 323, 411 (1986).

4. T. Kubo et al., FEBS Lett. 209, 367 (1986)

5. E. G. Peralta et al., Science 236, 600 (1987)

6. A. G. Gilman, Cell 36, 577 (1984); L. Stryer and H R. Bourne, Annu. Rev. Cell Biol. 2, 291 (1986); A. M. Spiegel, Mol. Cell. Endocr. 49, 1 (1987).

7. J. Nathans and D. S. Hogness, Cell 34, 807 (1983) J. Nathans, D. Thomas, D. S. Hogness, Science 232, 193 (1986)

8. R. A. F. Dixon et al., Nature (London) 321, 75 (1986).

9. Y. Yarden et al., Proc. Natl. Acad. Sci. U.S A. 83 , 6795 (1986); B. K. Kobilka et al., ibid. 84, 46 (1987); F:-Z. Chung et al., FEBS Lett. 211, 200 (1987).

10. H. Okayama and P. Berg, Mol. Cell. Biol. 3, 280 (1983)

11. T. I. Bonner, H.-U. Affolter, A. C. Young, W. S Young III, Mol. Brain Res., in press.

12. Complementary DNA clones were identified by hybridization to blots made from plasmid minipreparations of pools of clones in the cDNA library. The blots were hybridized in $6 \times$ standard saline citrate (SSC) $(0.9 M \mathrm{NaCl}, 0.09 M$ sodium citrate, $p \mathrm{H} 7.0)$ at $60^{\circ} \mathrm{C}$ to the 56 -nucleotide oligonucleotide that had been labeled with ${ }^{32} \mathrm{P}$ by using $\mathrm{T} 4$ polynucleotide kinase. Blots were washed under the same conditions as hybridized. The three cDNAs were identified as Bam $\mathrm{HI}$ and Xho I bands of the following sizes (in kilobases): $\mathrm{ml}, 1.8$ and $2.9 ; \mathrm{m} 3$, 2.8 and 3.9; and $\mathrm{m} 4,2.4$ and 1.05. The 0.51-kb Sac I-Pst I fragment corresponding to amino acids 55 to 224 of the $\mathrm{ml}$ cDNA was cloned into the pSP64 plasmid to make clone $\mathrm{cRml}$ 55, which was used as probe to screen genomic libraries by hybridization in $3 \times$ SSC at $60^{\circ} \mathrm{C}$

13. To conserve space the $8.7 \mathrm{~kb}$ of $\mathrm{cDNA}$ sequence and $10.5 \mathrm{~kb}$ of sequence from the two rat genes and the two human genes described below are not shown but have been deposited in the GenBank database (accession numbers Ml6404 to Ml6409). The ml, $\mathrm{m} 3$, and $\mathrm{m} 4 \mathrm{cDNAs}$ contain 1085,1769 , and 1145 bases of $3^{\prime}$ untranslated and 62,40, and 0 bases of 5 ' untranslated sequence, respectively. The sequences homologous to the oligonucleotide probe differ from the probe by 1,7 , and 9 nucleotides, respectively.

14. We propose that the porcine brain clone and its homologs from other species be called the $\mathrm{ml}$ receptors, not to signify the Ml receptor classification but to represent the first muscarinic receptor of defined primary structure. The porcine cardiac receptor thus becomes the $\mathrm{m} 2$ receptor as the second receptor to be sequenced, and the two new receptors that we have identified become the $\mathrm{m} 3$ and $\mathrm{m} 4$ receptors. 
15. Y. A. Ovchinnikov, FEBS Lett. 148, 179 (1982).

16. T. D. Sargent et al. Proc. Natl. Acad Sci. US. A. 76, 3256 (1979)

17. S. M. Mount, Nucleic. Acids Res. 10, 459 (1982).

18. T. I. Bonner and A. C. Young, unpublished data.

19. R. M. Lawn, E. F. Fritsch, R. C. Parker, G. Blake, T. Maniatis, Cell 15, 1157 (1978).

20. W. Gilbert, Nature (London) 271, 501 (1978); $\longrightarrow$ M. Marchionni, G. McKnight, Cell 46, 151 $\overrightarrow{(1986)}$

21. W. S. Young III, T. I. Bonner, M. R. Brann, Proc. Natl. Acad. Sci. U.S.A. 83, 9827 (1986).

22. M. Mishina et al., Nature (London) 307, 604 (1984).

23. T. Evans et al., Mol. Pharmacol. 27, 32 (1985); T. K. Harden et al., Trends Pharmacal. Sci. 7 (suppl.), 14 (1986).

24. M. R. Brann et al., Mol. Pharmacol., in press.
25. R. A. F. Dixon et al., Nature (London) 326, 73 (1987)

26. M. O. Dayhoff, R. M. Schwartz, B. C. Orcutt, in Atlas of Protein Sequence and Structure, M. O. Dayhoff, Ed. (National Biomedical Research Foundation, Silver Spring, MD, 1978), vol. 5, Suppl. 3, p. 345.

27. F. L. Graham and A. J. van der Eb, Virology 52, 456 (1973).

28. T. Evans, M. M. Smith, L. I. Tanner, T. K. Harden, Mol. Pharmacol. 26, 394 (1984).

29. We thank $M$. Brownstein for generously providing the cDNA library, H. Okayama and $M$. Brownstein for sharing their experience with the $\mathrm{PCD}$ expression vector, and W. Klee and A. Spiegel for helpful discussions.

15 May 1987; accepted 8 July 1987

\section{The CML-Specific P210 bcrlabl Protein, Unlike v-abl, Does Not Transform NIH/3T3 Fibroblasts}

\author{
George Q. Daley, Jami Mclaughlin, Owen N. Witte, \\ DAVID BALTIMORE
}

The v-abl oncogene of the Abelson murine leukemia virus (A-MuLV) is known to efficiently transform NIH/3T3 fibroblasts in vitro and to cause an acute lymphosarcoma in susceptible murine hosts. The role of its relative, the bcr/abl gene product, in the etiology of human chronic myelogenous leukemia (CML) remains speculative. To assess the transforming properties of the bcr/abl gene product, complementary DNA clones encoding the CML-specific P210 bcr/abl protein were expressed in NIH/3T3 fibroblasts. In contrast to the v-abl oncogene product P160, the P210 bcr/abl gene product did not transform NIH/3T3 cells. Cell lines were isolated that expressed high levels of the P210 bcr/abl protein but were morphologically normal. During the course of these experiments, a transforming recombinant of $b c r / a b l$ was isolated which fuses gag determinants derived from helper virus to the $\mathrm{NH}_{2}$-terminus of the bcr/abl protein. This suggests that a property of viral gag sequences, probably myristylation-dependent membrane localization, must be provided to $b c r / a b l$ for it to transform fibroblasts.

$\mathrm{T}$ The Philadelphia chromosome, a result of reciprocal translocation of distal segments of autosomes 9 and 22 , is found in greater than $90 \%$ of cases of human chronic myelogenous leukemia (CML) (1). The translocation juxtaposes cabl protooncogene sequences on chromosome 9 with a gene of unknown function, denoted bcr, on chromosome 22 (2). A novel hybrid messenger RNA transcribed from this locus directs the translation of a 210-kD phosphoprotein (P210) carrying both $b c r$ and $a b l$ antigenic determinants (3). The P210 bcr/abl protein resembles the v-abl oncogene product of Abelson murine leukemia virus (A-MuLV) in its high tyrosinespecific protein kinase activity (4). In addition, the P210 and v-abl proteins involve replacements of $\mathrm{NH}_{2}$-terminal c-abl sequences with bcr and viral gag sequences, respectively (5-7). To examine whether the CML-specific bcrlabl protein functions like the gag/v-abl protein of A-MuLV to transform fibroblasts in vitro, we tested various constructs which encode P210 bcrlabl.
These constructs do not transform fibroblasts, suggesting that $b c r / a b l$ functions differently from the $v$-abl oncogene product.

Previously, we isolated overlapping complementary DNA (cDNA) clones that define the complete coding sequence for the P210 borlabl gene product (8). Using these clones, as well as cDNA clones of the murine $c-a b l$ gene (9), we have made several constructs for use in expression studies in tissue culture cells (Fig. 1). The plasmid pJW-TX (Fig. 1A), containing the cDNA for the full-length coding sequences of P210 and the SV40 origin of replication, directs the transient expression in COS cells of a 210-kD phosphoprotein that is immunoprecipitated with antisera to $a b l$ and co-migrates with the P210 bcrlabl protein of K562 cells (Fig. 2A, lanes 1 and 2). The cDNA thus encodes a protein with the properties of the CML-specific P210.

To isolate cell lines that expressed the P210 protein in a stable manner, we attempted to directly transfect P210 constructs, but few transformants were found.
Knowing that abl-expressing constructs can be toxic to cells upon transfection (10), we co-transfected a construct that expressed P210 (pcEX6.5, Fig. 1C) with one expressing resistance to the antibiotic G418 (pSV2Neo) (11). Presence of the P210 construct resulted in a fivefold decrease in the number of G418-resistant colonies. Likewise, there was a strong negative selection against a transfected P210 construct bearing a co-selectable G418 resistance marker (pJW-RX in Fig. 1B). The apparent toxicity of P210-expressing constructs is similar to that of the v-abl gene product (10). To decrease the cytocidal effect of transfection of the bcrlabl cDNA, we attempted retroviral transduction of single copies of the toxic gene. Upon co-transfection of the pJW-RX construct with a construct encoding Moloney helper virus pZAP (12) and subsequent selection with G418, cell lines were isolated that stably expressed high levels of the P210 protein (Fig. 2B, lanes 1 and 2). The level of P210 kinase activity in these cell lines was comparable to or greater than P160 v-abl kinase activity in A-MuLVtransformed cells (Fig. 2B, lane 5). In a separate experiment, transfection of the retroviral-packaging cell line $\phi-2$ (13) with pJW-RX and subsequent selection with G418 gave helper-free retroviral producer cell lines, which were screened for production of high levels of virion RNA (14). Cell lines selected in this manner expressed particularly high levels of P210 kinase activity (Fig. 2C, lane 1). Supernatants from these $\phi-2$ producer cell lines transferred the P210 bcrlabl gene product by retroviral infection (Fig. 2C, lane 3). P210-expressing cell lines all appeared morphologically flat and were readily distinguished from cells transformed by the v-abl oncogene product (compare $\mathrm{C}$ and $\mathrm{D}$ of Fig. 3).

During experiments in which the pLTR6.5 construct (Fig. 1D) was co-transfected with the replication-competent Moloney helper virus pZAP (12) onto NIH/ 3T3 cells, a low frequency of transformed foci arose (less than $1 \%$ of control v-abl constructs). These transformed foci resembled those of v-abl (compare B and D of Fig. 3 ), and cell lines established from these foci produced high titers of virus capable of transforming $\mathrm{NIH} / 3 \mathrm{~T} 3$ cells at a frequency comparable to A-MuLV (15). To determine the nature of the transforming protein or proteins responsible for the transformation

G. Q. Daley and D. Baltimore, Whitehead Institute for Biomedical Research, Nine Cambridge Center, Cambridge, MA 02142, and Department of Biology, Massachusetts Institute of Technology, Cambridge, MA 02139.

02139 . cal Institute, Department of Microbiology and Molecular Biology Institute, University of California, Los Angeles, CA 90024. 